\title{
Rainwater Management Solutions and their Impact on Shaping Inner City Areas Undergoing Transformation (Case Study of the ZAC Clichy-Batignolles Area in Paris)
}

\author{
Renata Jóźwik \\ Department of Landscape Architecture, University of Life Sciences in Lublin, Akademicka 13, 20-950 Lublin, \\ Poland \\ e-mail: renata.jozwik@up.lublin.pl
}

\begin{abstract}
Proper management of rainwater in cities has a significant impact on improving the environmental conditions: the microclimate of a city by regulating the water cycle and reducing heat islands; developing of biodiversity; increasing health and well-being of residents. The aim of the article was to present the possibilities of improving the environmental conditions in compact urban development areas - those that additionally contribute to the shaping of architecture, and thus combine the ecological, functional, and aesthetic benefits. The article draws attention to the synergy of climate change and the new way of developing urban areas, which was presented on the example of specific solutions functioning on the transformed urban area: Clichy-Batignolles in central Paris - recognized as a model for environmental solutions, labelled Éco-Quartier. The mentioned conditions and solutions were related to the possibility of shaping urban form, with the obligation to discharge some or all of the rainwater on the building plot. On the basis of the calculations made for the runoff ratio in individual quarters, it was found that it is possible to maintain a compact urban structure and effectively manage rain water provided that appropriate engineering and urban solutions are applied. These solutions can have an architectural value. The conclusions from the analyses can be used to formulate guidelines for other European cities, which are increasingly faced with the problem of water scarcity and uncontrolled flooding.
\end{abstract}

Keywords: new urban development, Sustainable Urban Water Management, rainwater harvesting, wet ditches, biotope reservoir, runoff ratio, degraded areas, Clichy-Batignolles area

\section{INTRODUCTION}

Global climate change, as well as the process of progressive and dynamic urbanization, excessive compacting of buildings in cities, implemented in accordance with the idea of a compact city [Breheny 1995; Gordon \& Richardson 1997; Compact cities.. 2000; European Commission 2007; Conticelli 2019], can cause a real threat to environment in the form of disturbances in water circulation in the city environment [Eckert \& Huynh 2016]. As a result of the increased built-up and tightly paved areas, as well as the development of underground buildings, water does not soak into the ground and does not evaporate sufficiently to the atmosphere to regulate the natural climate processes. These conditions contribute to the increase of air temperature in cities even by a few degrees (heat islands) [Oke 1982; Oke et al. 2017; Zimny 2006; Giridharan \& Emmanuel 2018] and to the emergence to extreme weather situations, which may result in, for example, destructive droughts or flooding during intense, rapid rainfalls. In the built-up areas, an increase of the surface runoff speed [Leopold 1968], overload of inefficient sewer systems and decrease of the groundwater level, are being observed. Such areas become poorer in the vegetation because they do not provide adequate conditions and place for the development of stable ecosystems. As a result, health and life conditions of residents are also becoming unfavorable. Proper management 
and reuse of rainwater is also a way to protect the drinking water, as a result of reducing its usage for non-food purposes [Anderson 2003; Zhang et al. 2009]. Studies show that the level of drinking water savings in households can reach up even to 60\% [Skwarzyńska \& Jóźwiakowski et Al. 2014].

The discharge of rainwater to sewer systems is associated with the risk of water contamination in rivers, and wastewater treatment, constant maintenance of sewer systems is expensive [Stewart \& Hytiris 2008]. It is a process focused on only one aspect - fast drainage of water from a place of rainfall. In addition, the water is treated as a nuisance, not as a resource; also, it does not integrate other important aspects: recreational, visual, landscape, ecological, etc. [Zhou 2014]. In natural areas, only about $20 \%$ of rainwater flows down into the rivers. In urban areas, this runoff reaches even 80\% [Markowič et. al 2014].

Balancing water circulation in an urban environment (both in the atmosphere and on the surface), achieving ecological stability related to it, and protecting drinking water reservoirs by limiting the exploitation of water resources for purposes other than consumption, are key for the ecological benefits. The selected criteria of strategy in this activity should take into account the following aspects: health and hygiene, social and cultural considerations, environmental and economic aspects, technical possibilities [Hellstörm et al. 2000]. The scope of benefits resulting from Sustainable Urban Water Management (SUWM) has also been well-documented during the last decades [e.g. Chocat et al. 2007; Wong and Brown 2008; Belmeziti et al. 2015].

Many of the solutions applied for rainwater management have a potential of interesting spatial shaping and being introduced under urban conditions - can have artistic or architectural value [Echols 2007]. This is one of the issues of adapting cities to global changes related to the climate change [Carter 2011]. Up to now, the experiences in the field of urban transformation were based on other guidelines. There were focused on: creation of multi-functional areas, optimal economic use of space, improvement of the social dimension of cities, and support for biodiversity in cities. Currently, the catalogue of solutions is expanding, which affects the image of cities diametrically.

Sustainable development of cities is the goal of many systemic international activities. In 1994, the Charter of European Cities \& Towns Towards
Sustainability was published in Aalborg [European Commission 1994]. In its scope, apart from general provisions of the declarations, there were assumptions, possibilities and local action plans towards implementation of sustainable development as a result of the Agenda 21.

The Leipzig Charter for Sustainable European Cities was signed in 2007 [European Commission 2007]. It promotes dense urban structures, protection of natural resources, and adaptation of cities to the changing climate. Subsequent proposals for sustainable cities are becoming more detailed. On the initiative of the European Union, publication entitled The City of Tomorrow - Challenges, Visions, Perspectives published in 2011 [European Commission 2011], shows the main directions of the measures, good practices and solutions that are expected of "smart cities".

The sustainable solutions for rainwater harvesting are the subject of various design strategies that have been developing effectively since the 1990s - e.g. Low Impact Development (LID) in the US and Canada, Sustainable Drainage Systems (SuDS) in Great Britain, Water Sensitive Urban Design (WSUD) in Australia and the Middle East [Fletcher et al. 2015].

The rainwater management is the application of such solutions, which mainly include: water infiltration, excess rainwater harvesting (RWH), outflow delay and pollution reduction in water. The appropriate management of rainwater is of great importance for the functioning of cities, because the balance of rainfall and runoff, soaking into the ground and evaporation is shaken [Słyś 2013].

The aim of the paper, by analyzing the best practices, was to show the dependence between shaping the urban form in the areas of compact development and the systemic management of rainwater [Getnet \& MacAlister 2012]. The Clichy-Batignolles area in Paris was selected for the analysis as an example of the urban transformation, where from the beginning the environmental conditions for the rainwater protection were assumed to be improved. In addition, the legal conditions have been imposed in the meantime to shape new facilities that oblige to retain rainwater within a building plot. This finally translates into urban form and architectural solutions. The study consisted in calculating the runoff ratio for individual building quarters and referring the results to general assumptions. 


\section{RAINWATER MANAGEMENT ON ZAC CLICHY-BATIGNOLLES AREA IN PARIS}

According to the rainwater management plan drawn up for Paris, [Arrêté ... 2015] the city was divided into four types of areas - rain zones, for which the limitations in rainwater drainage to the sewerage system were set and obliged implementing solutions contributing to the protection by rainwater harvesting. The regulations refer to newly developed and reconstructed plots and have been linked to other spatial planning documents: the Paris development plan (Plan Local d'Urbanisme de Paris); a plan for protection and development (Plan de Sauvegarde et de Mise en Veleur); Parisian sanitary regulations (Règlement d'Assainissement de Paris); Planning and Sustainability Project (Projet d'Aménagement et du Développement durable) [Mairie de Paris 2018b].

In Paris, the following 4 zones of rainwater runoff were determined as: total (green), reinforced allowance (yellow), normal (orange) and reduced (red) (Figure 1). For individual areas, a twofold, alternative way of calculating the allowed runoff of rainwater into the sewerage system was defined, i.e. preferential - based on the threshold rule and admissible - based on the percentage rule (Table 1, Table 2).

The percentage rule is considered as less effective. It is used in a special case when the devices used for reduction of run-off are not able to reach the values specified in the threshold rule. Therefore, an investor can justify the approach to the development of the plot by the percentage rule, according to the established percentage zones.

According to this principle, division into rainwater drainage zones into the ground and sewage system is carried out with reference to $16 \mathrm{~mm}$ rainfall (Table 2). In case of heavy rainfall, exceeding $16 \mathrm{~mm}$, the excess rainwater is discharged to the sewerage system.

The presented zone division is obligatory from 2016 and results in the need to obtain the permission for rainwater discharges at the construction or reconstruction stage, on request owner (investor) before submitting the construction project or plot development (Autorisation de rejet des eaux pluviales - AREP). An investor submits for this purpose: building design, plot development, plan of connections, calculations regarding volume of

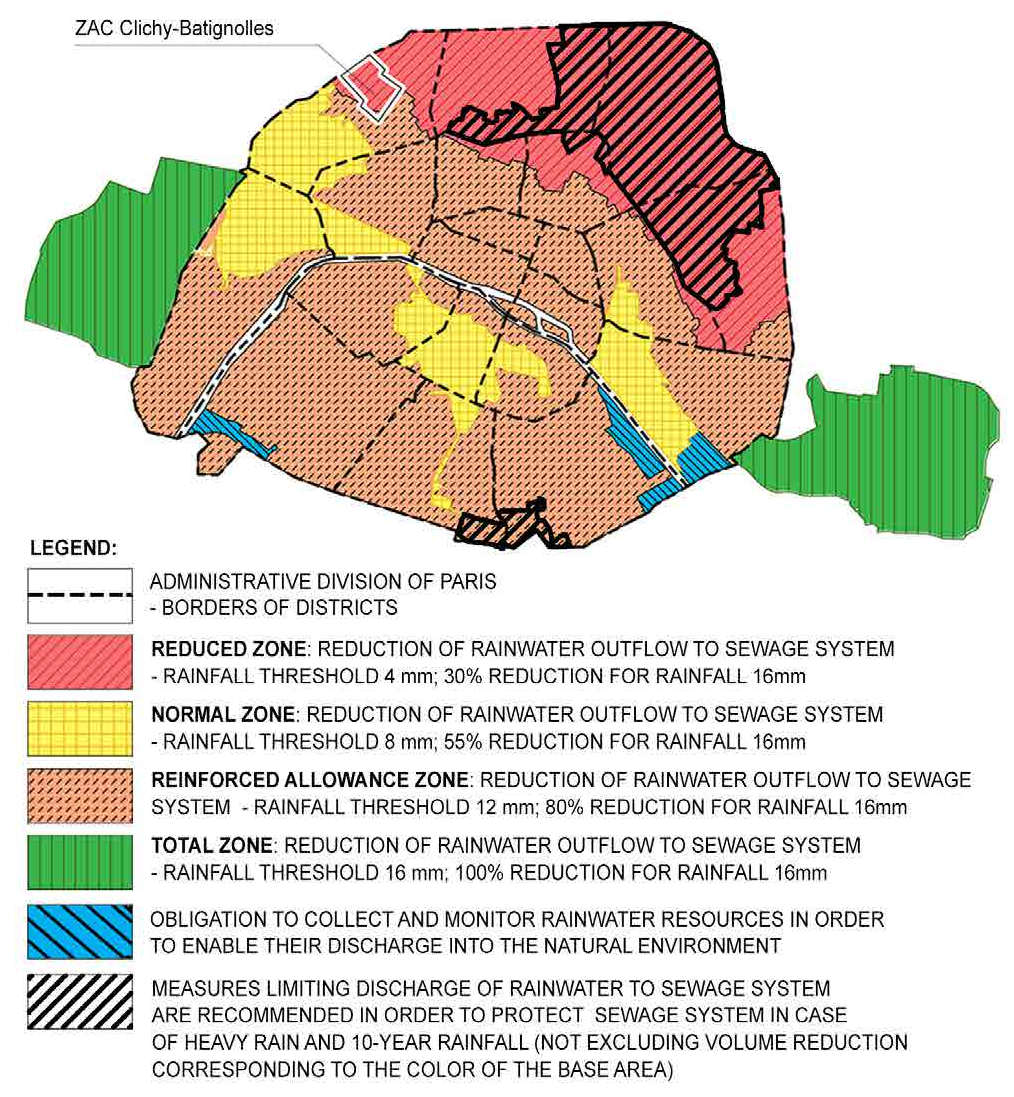

Fig. 1. Areas of restriction of rainwater drainage in Paris.

Based on Carte du Zonage Pluvial [Mairie de Paris 2018a]. 
Table 1. Limitations in rainwater drainage to the sewage system - threshold rule.

\begin{tabular}{|c|c|c|c|}
\hline \multicolumn{2}{|c|}{$\begin{array}{l}\text { Limitations zone; rainfall } \\
\text { threshold } \mathrm{H}_{\mathrm{z}}[\mathrm{mm}]\end{array}$} & \multirow{2}{*}{$\frac{\text { Volume of rainfall outflow } V_{u}[l]}{16000}$} & \multirow{2}{*}{$\begin{array}{l}\text { Volume of rainfall outflow to sewage system } \mathrm{V}_{\text {rejet }}[1] \\
0 \text { - if rainfall is less than } 16 \mathrm{~mm} \text {; excess rain water } \\
\text { (more than } 16 \mathrm{~mm} \text { ) outflows to sewage system; }\end{array}$} \\
\hline Total & 16 & & \\
\hline $\begin{array}{l}\text { Reinforced } \\
\text { allowance }\end{array}$ & 12 & 12000 & $\begin{array}{l}0 \text { - if rainfall is less than } 12 \mathrm{~mm} \text {; excess rain water } \\
\text { (more than } 12 \mathrm{~mm} \text { ) outflows to sewage system; }\end{array}$ \\
\hline Normal & 8 & 8000 & $\begin{array}{l}0 \text { - if rainfall is less than } 8 \mathrm{~mm} \text {; excess rain water } \\
\text { (more than } 8 \mathrm{~mm} \text { ) outflows to sewage system; }\end{array}$ \\
\hline Reduced & 4 & 4000 & $\begin{array}{l}0 \text { - if rainfall is less than } 4 \mathrm{~mm} \text {; excess rain water } \\
\text { (more than } 4 \mathrm{~mm} \text { ) outflows to sewage system; }\end{array}$ \\
\hline \multicolumn{2}{|c|}{ Calculation formula } & $\begin{array}{ll}V_{u}=S_{\text {réfu }} \cdot H_{p} & H_{p}<=H_{z} \\
V_{u}=S_{\text {réfu }} \cdot H_{z} & H_{p}>H_{z}\end{array}$ & $\begin{array}{ll}V_{\text {rejet }}=0 & H_{p}<=H_{z} \\
V_{\text {rejet }}=S_{\text {rétu }} \cdot\left(H_{p}-H_{z}\right) & H_{p}>H_{z}\end{array}$ \\
\hline
\end{tabular}

$\mathrm{V}_{\mathrm{u}}$ - Volume of rainfall on the surface area; $\mathrm{S}_{\text {réfu }}$ - surface area for calculation; $\mathrm{H}_{\mathrm{p}}$ - amount of rainfall; $\mathrm{H}_{\mathrm{z}}-$ rainfall threshold; $\mathrm{V}_{\text {rejet }}$ - volume of rainfall outflow to sewage system

On the basis of: Zonage d'assainissement de la Ville de Paris. Projet soumis à enquête publique. Annexes au règlement [Mairie de Paris 2016].

Table 2. Limitations in rainwater drainage to the sewage system - the percentage rule.

\begin{tabular}{|l|c|l|l|}
\hline \multicolumn{2}{|l|}{ Limitations zone for rainfall $16 \mathrm{~mm}$} & \multicolumn{1}{|c|}{ Volume of rainfall outflow $\mathrm{V}_{\mathrm{u}}[\mathrm{l}]$} & \multicolumn{1}{c|}{$\begin{array}{c}\text { Volume of rainfall outflow to sewage system } \mathrm{V}_{\text {rejet }} \\
{[\mathrm{l}]}\end{array}$} \\
\hline Total & $100 \%$ & for rainfall $16 \mathrm{~mm}: 16000$ & 0 \\
\hline $\begin{array}{l}\text { Reinforced } \\
\text { allowance }\end{array}$ & $80 \%$ & for rainfall $12 \mathrm{~mm}: 9600$ & 2400 \\
\hline Normal & $55 \%$ & for rainfall $8 \mathrm{~mm}: 4400$ & 3600 \\
\hline Reduced & $30 \%$ & for rainfall $4 \mathrm{mm:} 1200$ & 2800 \\
\hline Calculation formula & & $\begin{array}{l}\mathrm{V}_{\mathrm{u}}=\mathrm{S}_{\text {rétu }} \cdot \mathrm{H}_{\mathrm{p}} \quad \mathrm{H}_{\mathrm{p}}<=\mathrm{H}_{z} \\
\mathrm{~V}_{\mathrm{u}}=\mathrm{S}_{\text {rétu }} \cdot \mathrm{H}_{\mathrm{z}} \mathrm{H}_{\mathrm{p}}>\mathrm{H}_{z}\end{array}$ & $\begin{array}{l}\mathrm{V}_{\text {rejet }}=0 \\
\mathrm{~V}_{\text {rejet }}=\mathrm{S}_{\text {rétu }} \cdot\left(\mathrm{H}_{\mathrm{p}}-\mathrm{H}_{\mathrm{z}}\right) \quad \mathrm{H}_{\mathrm{p}}<=\mathrm{H}_{z}\end{array}$ \\
\hline
\end{tabular}

On the basis of: Zonage d'assainissement de la Ville de Paris. Projet soumis à enquête publique. Annexes au règlement [Mairie de Paris 2016].

rainwater and possibilities of drainage, area of plot, percent of biologically active area, etc.

This is a general change in the approach involving the legal conditions, which must be adapted to the local conditions [Campisano et al. 2017]. However, the French example can be referred to as a model for other European countries.

\section{ZAC CLICHY-BATIGNOLLES AREA}

A study on the dependence of the rainwater management on shaping of urban form has been extended to the railway area of Clichy-Batignolles in Paris, the new development of which has been ongoing since 2001. Its original, eco-friendly idea was related to the fact that the area was proposed as a place for the Olympic Games in 2012 After choosing London as the host of the Olympics, the idea of creating an environmentally friendly area was maintained and the theme of water became one of the most relevant.

Currently, the area is considered as a model in terms of pro-environmental solutions owing to: promoting biodiversity, using renewable energy sources, sustainable rainwater management and innovative waste management. Planned from the beginning, as ZAC area - Les zones d'aménagement concerté (joint development zone) it has been labelled Éco-Quatier. The Martin Luther King Park received the Ecojardin Award in 2015.

The analysis focused in particular on the areas of new building quarters and park, which constitutes in total $49.2 \%$ from 50.72 ha area. The analysis aims to determine the dependence between the location of compact buildings, the possibility of using rain absorbing solutions and rainwater recovery as well as to estimate its scale within the plot in such areas. In the future, it can be used to determine urban parameters and guidelines for similar areas in other places.

The Paris area of ZAC Clichy-Batignolles (50.72 ha) has been divided into 4 types of land, which differ in terms of rainwater drainage, allowing the calculation of average rainwater runoff ratio:1) Martin Luther King Park 10.27 ha $\left(\Psi_{p}=0.239\right)$; 2) new building quarters 
A-H - 14.70 ha ( $\left.\Psi_{\mathrm{a}-\mathrm{h}}=0.656\right)$; 3) existing, developed areas - mainly quarters of compact development 9.5 ha $\left(\Psi_{\mathrm{q}}=0.8\right)$; 4) infrastructure areas (railway, main roads with few lawns) -16.20 ha $\left(\Psi_{\mathrm{i}}=0.8\right)$ (figure. 2$)$. The average rainwater runoff ratio for the total ZAC area is $\Psi_{\text {zac }}=0.645$.

The first group of areas, covering types 1 and 2 , constitutes almost half of the area $(49.2 \%)$. They have been transformed completely with taking into account the issue of rainwater drainage. During the urban transformation period, there were no obligatory restrictions in this respect. The average runoff ratio is much lower than in the existing areas. Other areas, former developed and infrastructure areas, can be considered as subject to the existing classical drainage method - mainly to a sewage system. The possibilities of transformations in these areas are much smaller than in the first, analyzed group, where the average ratio has been reduced mainly due to the location of greenery on roofs.

The average annual precipitation in Paris for the long-term 1981-2010 is $637.7 \mathrm{~mm}$. The highest atmospheric precipitation is recorded in May $(63.2 \mathrm{~mm})$, and the lowest in February (41.2 mm), (Table 3) [MeteoFrance 2019]. This data enables to calculate the monthly and annual volume of water from rainfall discharged to the sewerage system.

On the basis of the calculations above, an average of $114,800 \mathrm{~m}^{3}$ of water is absorbed into the ground or stored and intended for reuse in the studied area on an annual basis. The occurrence of underground car parks on a large part of plots encourages the use of solutions to retain water due to limited absorption into the ground. In old quarters of development, the runoff ratio is greater, but the absorption into the ground is also higher, because there is more land without underground structures. Therefore, these deficiencies must complement the green areas, which is the role of Martin Luther King Park in this area.

\section{MARTIN LUTHER KING PARK}

Martin Luther King Park (landscape architecture Atelier Jacqueline Osty) with an area of 10.28 ha constitutes $19.5 \%$ of the total ZAC Clichy-Batignolles area (fig.3). The biologically active area (mainly plants on native soil) covers an area of $46920 \mathrm{~m}^{2}$ (46.6\% of park area, $\Psi_{\mathrm{pb}}=0.05$ ); hardened surfaces (mostly permeable) are $4.4200 \mathrm{~m}^{2}\left(43 \%\right.$ of park area, $\left.\Psi_{\mathrm{a}}=0.5\right)$;

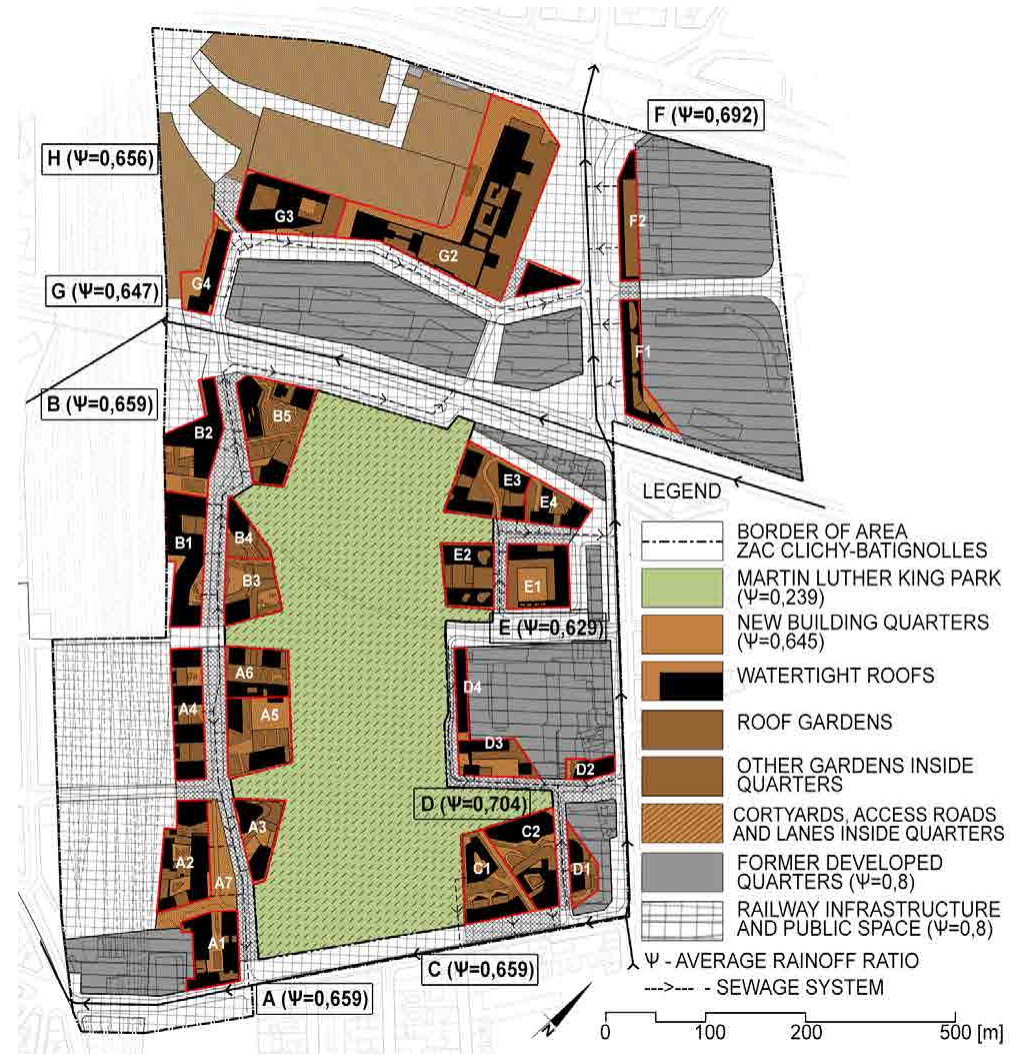

Fig. 2. Land division in terms of drainage method 
biotope reservoirs, canal and wet ditches account for almost $11 \%$ of park area $\left(\Psi_{w}=0.01\right)$. The average runoff ratio for the entire park is $\Psi_{\mathrm{p}}=0.239$.
Park uses rainwater in a systemic way. Only exceptionally heavy rainfall requires support through a sewage system. $40 \%$ hydration of park

Table 3. Monthly and annual precipitation [MeteoFrance 2019] and volume of rainoff in ZAC ClichyBatignolles area (Paris)

\begin{tabular}{|l|c|c|c|c|c|c|c|c|c|c|c|c|c|}
\hline \multicolumn{1}{|c|}{ Month } & I & II & III & IV & V & VI & VII & VIII & IX & X & XI & XII & $\begin{array}{c}\text { Annual } \\
\text { value }\end{array}$ \\
\hline Precipitation [mm] & 51 & 41,2 & 47,6 & 51,8 & 63,2 & 49,6 & 62,3 & 52,7 & 47,6 & 61,5 & 51,1 & 57,8 & 637,7 \\
\hline $\begin{array}{l}\text { Rainoff in ZAC } \\
\text { Clichy-Batignolles } \\
\text { area [thousands m } \text { m }^{3} \text { [ }\end{array}$ & 16,7 & 13,5 & 15,6 & 16,9 & 20,7 & 16,2 & 20,4 & 17,2 & 15,6 & 20,1 & 16,7 & 18,9 & 208,7 \\
\hline
\end{tabular}

$\mathrm{Q}=\mathrm{P} * \mathrm{~A} * \Psi$

$\mathrm{Q}$ - volume of rainfall on the area; $\mathrm{P}$ - precipitation; $\mathrm{A}=507237 \mathrm{~m} 2$ - surface area; $\Psi=0,645$ - average rainwater runoff ratio.

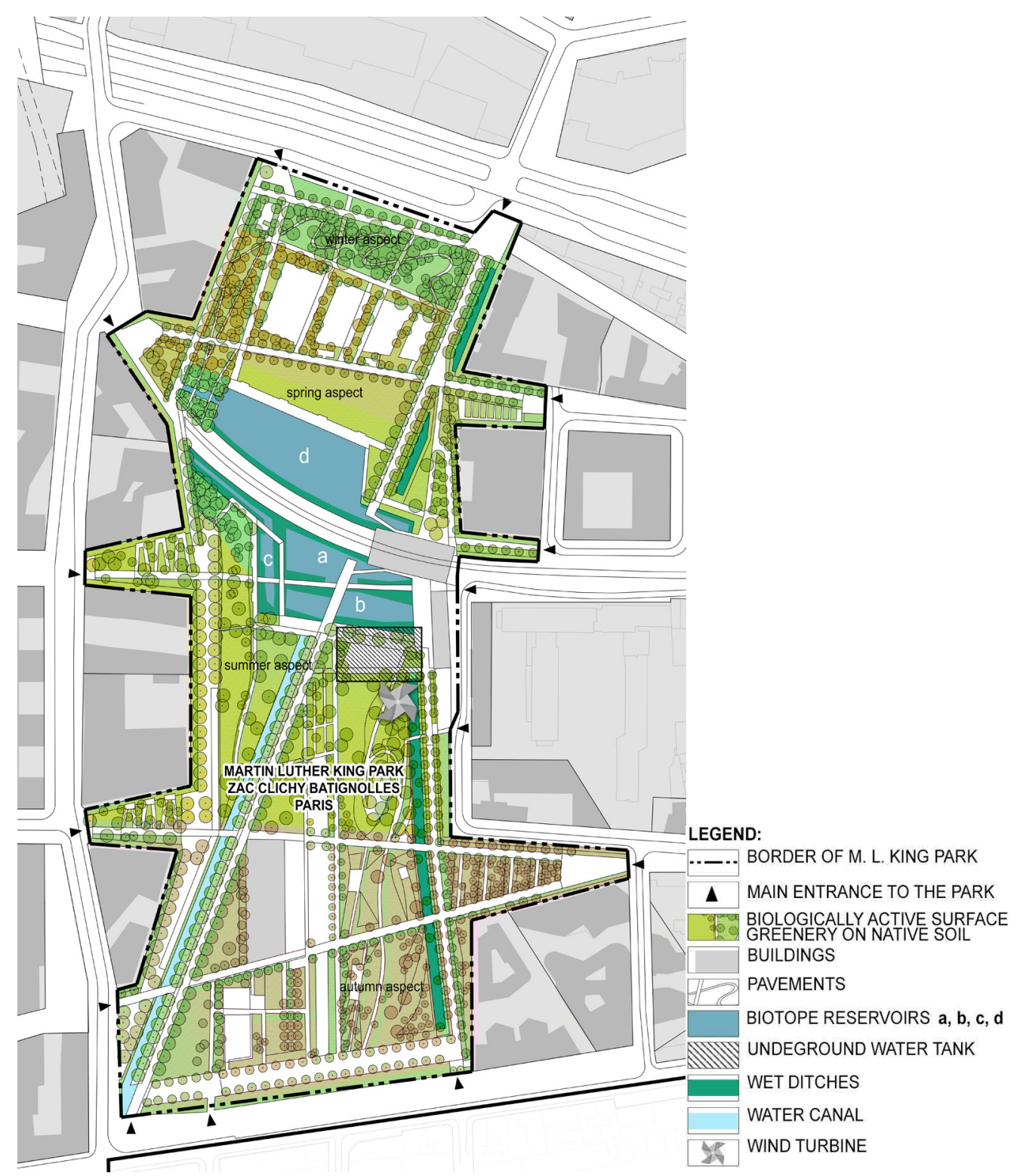

Fig. 3. Park plan with elements of rainwater management system.

Based on park plan by the Atelier Jacqueline Osty [Atelier Jacqueline Osty \& associés 2019]. 
is achieved owing to the recovery of rainwater. This area is realized in three stages: 4.5 ha of north-east part was created until 2007 (from the side: Rue Cardinet;) north-west part was opened in 2014; the last southern part will became available in 2020 and the investment will be completed.

The greenery of the park is generally integrated with building quarters - only in few places it is separated by roads. The whole area is fenced (or separated in other ways) and available at certain times. The park entrances were designed in 14 places.

Special elements of rain water management in park are integrated with each other: wet ditches, biotope reservoir and a special underground water reservoir.

Absorbent ditches (wet ditches) and other surfaces covered with hydrophytes designed inside park (along the main pedestrian routes and on edges of biotope reservoirs), constitute a type of rain gardens and at the same time are a component of the rainwater management system. They are aimed at collecting the excess of rainwater from impermeable surface (mainly pedestrian routes) and then naturally cleansing it through the process of infiltration and owing to the properties of hydrophytes.

The ditches constitute troughs with the bottom of the dimensions - in total: $207 \times 5 \times 0.5$ [m], in which the drainage system is located, transporting the purified water to the water reservoir. They are able to take about $500 \mathrm{~m}^{3}$ of water $(500,000 \mathrm{l})$. In dry periods, they are supplied with water from one of biotope reservoirs. Water is pumped with the help of wind turbine. In this case, the following plant species were used: water lily (Nymphaea alba L.), iris (Iris pseudoacorus L.), reed (Phragmites L.), flowering rush (Butomus umbellatus
L.), purple loosestrife (Lythrum salicaria L.), carex (Carex L.), club rush (Scirpus L.), lesser bulrush (Typha angustifolia, L.), the dotted loosestrife (Lysimachia punctata L.) (photos 1-5).

The rainwater, which is non-potable, flows sequentially through 4 biotope reservoirs, which are used for various tasks aimed at the natural purification of water (Fig. 4). First, the rainwater flows into the reservoir "a", where impurities are deposited via sedimentation. Then, the water flows into the reservoirs "b" where water goes through the process of decantation, with the support of positive bacteria used to decomposition of pollutants. A complete decomposition of pollutants takes place in the reservoir " $c$ ". At the last stage, after cascading water flow, already purified water is controlled in the reservoir " $\mathrm{d}$ " and then used e.g. for watering the vegetation in the park.

The water from wet ditches and from the biotope reservoir "d" is stored in a special, underground reservoir with a capacity of $1500 \mathrm{~m}^{3}$, from where it is pumped into the irrigation of the park. The tank is placed under a square with a floor fountain. A wind turbine located nearby is used to supply the pumps. Reservoirs are the habitat for aquatic fauna. In addition to the presented system of cleaning and storage of rainwater, it penetrates into the ground during rainfall, where natural infiltration takes place. The water is partly evaporated to the atmosphere through the evapotranspiration process.

\section{NEW BUILDING QUARTERS}

The calculations in the area of new building quarters were made on the basis of a drawn plan in DWG vector format. The division and

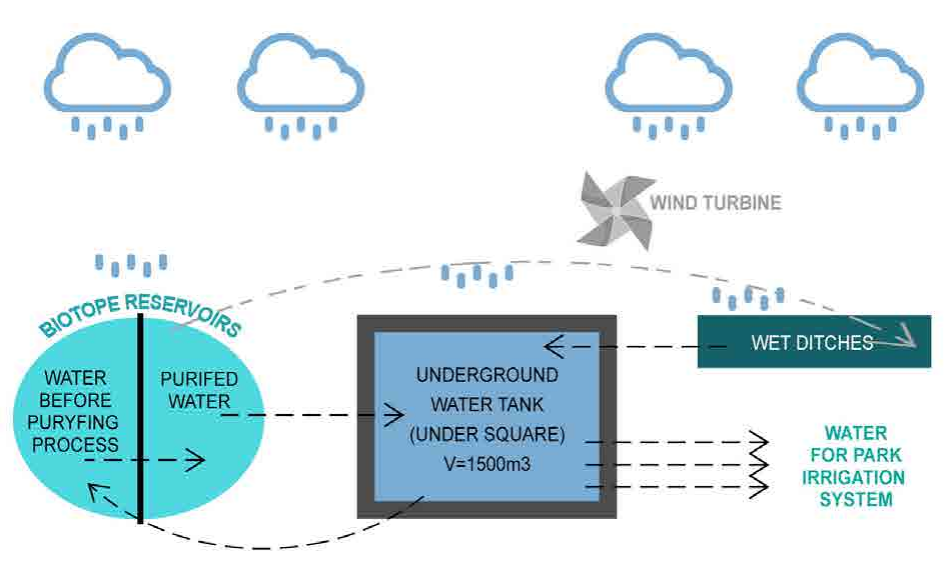

Fig. 4. Scheme of rainwater management system in the Martin Luther King Park 

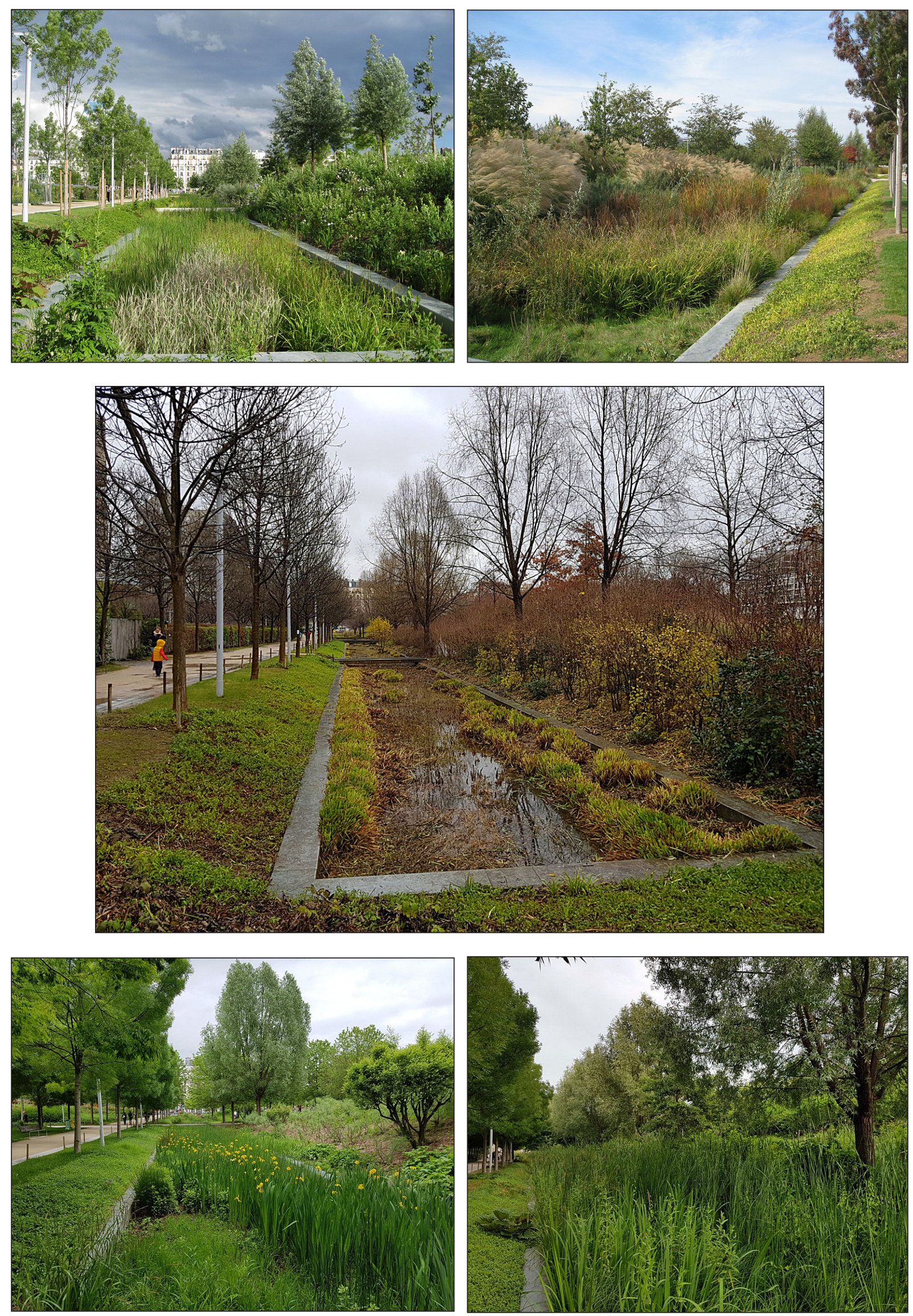

Photos 1-5. Wet ditches overgrown with hydrophytes (Phot. D. Favre) 
calculations inside the quarters were made on the basis of separate architectural designs or completed investments (Fig. 2).

The building quarters were divided into the areas for which appropriate runoff ratios were assumed: watertight roofs $\left(\Psi_{\mathrm{r}}=0.95\right)$; roof gardens $\left(\Psi_{\mathrm{rg}}=0.3\right)$; gardens on underground objects and other gardens inside quarters $\left(\Psi_{\mathrm{og}}=0.2\right)$; surfaces related to communication inside quarters $\left(\Psi_{\mathrm{wl}}=0.6\right)$.

The area balance allowed calculating the average runoff ratio for individual A-G quarters and the average gross ratio for this type of land, which is between 0.647-0.704. No measurement was taken for the $\mathrm{H}$ area due to the lack of detailed data on the future development. Due to the small difference in the value of ratio $\Psi$ between particular quarters, the average value of 0.656 was assumed also for area $\mathrm{H}$. While modelling quarters and using gardens on roofs and other solutions, the rainoff ratio was lower (in spite of $70 \%$ of buildings) than in the existing old quarters, where it averaged 0.8 on low-density development but without the use of the water drainage solutions.

The average percentage of buildings in quarters is $70 \%$; thus, they are characterized by high compactness. The remaining areas inside quarters are mostly courtyards and access roads, i.e. hardened, partially water permeable paving. In this type of developed areas, there are almost no traditional gardens or greenery on the native soil. The existing green areas are mostly designed on underground car parks, that is, they are usually gardens on concrete platforms. However, it is assumed that they can partly store rainwater. On average, it is assumed that green roofs are able to receive $60-70 \%$ of rainwater. In the case of intense rainfall, the range drops to $10-30 \%$ [Burszta-Adamiak et al. 2014]. In the calculation for ZAC Clichy-Batignolles area, the $80 \%$ index was adopted due to the frequently occurring integrated water storage system. In the area in question, the roofs of buildings are covered by photovoltaic panels in more than $50 \%$; then, the rainwater from these areas must be completely drained into sewage system.

The scale of occurrence of this phenomenon, i.e. the difficult conditions for soaking rainwater into ground shows how important it is to balance the entire urban area through a large green area, such as a nearby park.

In private areas, approximately only $70 \%$ of the rainwater was drained to the sewerage system through green gardens on the roofs; thus, the partial retention of water as part of its own plot was applied. Rainwater is used, for example, for cleaning outdoor surfaces, flushing toilets [Mairie de Paris 2015].

\section{CONCLUSIONS}

The use of wet ditches, green areas within the public space, setting gardens on roofs and rainwater storage as part of their own plot, as well as minimizing the use of tight surfaces may reduce the average runoff rate, also with the assumption of maintaining compact buildings. The storage of excess water after pre-treatment allows it to be reused, which contributes to the protection of drinking water resources and water purity in rivers. The analysis of the contemporary urban structure and the guidelines of sustainable rainwater management induce estimation of space already at the urban design stage. In the future, this may result in a mandatory requirement to meet the runoff ratio. These criteria can be achieved not only by determining the index of biologically active surface. Therefore, to shape effective areas for rainwater drainage and storage, a counting system based on runoff ratios for areas with different rainwater absorptivity and a land use map can be helpful.

The tool for assessment and management of the rainwater drainage 'Rainwater +' supporting the architect's workshop, integrated with the computer system (CAD) was designed by Chen et al. [2016]. The studies showed that integrating rainwater management with modelling at the project stage is crucial to determining the practice of Low Impact Drainage (LID). There is also a need to visualize the flow direction, helping to locate LID practices in the right places when the area is very complex.

Microretence and retention of rainwater in the areas of compact development can be helpful in shaping the diverse urban form, prompting to take into account the development of larger green areas and to improve the water cycle in the city (water reservoir, rain gardens, wet ditches, absorbent tanks, green roofs, vertical gardens and other elements of rainwater management systems.

The application of water elements in the urban space supports the activities to enrich biodiversity. It causes retention of water, stopping the spreading of soil contamination, increasing groundwater resources, i.e. their protection, and 
protection of surface waters. It is also an activity supporting the creation of new, innovative urban, architectural and landscape forms.

Potential economic benefits that can be obtained are: reduction of the water and wastewater fees, increase of safety level and lower risk of disasters; savings resulting from the reduction in the construction and operation of sewerage systems, increase in the value of plot due to the high quality of the landscape and pro-ecological space.

Implementation of pro-environmental projects of urban significance, requiring an integrated approach, is connected with the necessity of project management by a specialist design offices, which can coordinate the various stages and elements of the system.

\section{REFERENCES}

1. Anderson J. 2003. The environmental benefits of water recycling and reuse, Water Spply, Vol. 3., No 4., 1-10. [Access 2.06.2019]. Available at: https:// doi.org/10.2166/ws.2003.0041.

2. Arrêté du 21 juillet 2015 relatif aux systèmes d'assainissement collectif et aux installations d'assainissement non collectif, à l'exception des installations d'assainissement non collectif recevant une charge brute de pollution organique inférieure ou égale à $1,2 \mathrm{~kg} / \mathrm{j}$ de DBO5. [Access 2.06.2019]. Available at: www.legifrance.gouv.fr/ eli/arrete/2015/7/21/DEVL1429608A/jo/texte.

3. Atelier Jacqueline Osty \& associés. 2019. [Access 2.06.2019]. Available at: http://www.osty.fr/

4. Belmeziti A., Cherqui F., Tourne A., Granger D., Werey C., Le Gauffre P. \& ChocatB. 2015. Transitioning to sustainable urban water management systems: how to define expected service functions?, Civil Engineering and Environmental Systems, 32:4, 316334, DOI: $10.1080 / 10286608.2015 .1047355$

5. Breheny M.J. 1995. The Compact City and Transport Energy Consumption. Transactions of the Institute of British Geographers, New Series, No. 20(1), 81-101.

6. Burszta-Adamiak E., Łomotowski J., Wiercik P. 2014. Zielone dachy jako rozwiązaniami poprawiające gospodarkę wodami opadowymi w miastach [Green roofs as solutions to improve rainwater management in cities]. Inżynieria ekologiczna, Vol. 39. 26-32, DOI: 10.12912/2081139X.47.

7. Campisano A., Butler D., Ward S., Burns M.J., Friedler E., DeBusk K., Fisher-Jeffes L.N., Ghisi E., Rahman A., Furumai H., Han M. 2017. Urban rainwater harvesting systems: research, implementation and future perspectives. Water Research, Vol. 115, 195-209.
8. Carter J.G. 2011. Climate change adaptaion in European cities. Current Opinion in Environmental Sustainbility, Vol 3. issue 3., 193-198.

9. Chen Y., Samuelson H.W., Tong Z. 2016. Integrated design workflow and a new tool for urban rainwater management. Journal of Environmental Management, Vol. 180,. 45-51. [Access 2.06.2019]. Available at: https://doi.org/10.1016/j. jenvman.2016.04.059.

10. Chocat, B., Ashley R., Marsalek J., Matos M.-R., Rauch W., Schilling W., and Urbonas B. 2007. Toward Sustainable Management of Urban Storm Water. Indoor Built Environment 16 (3), 273-285.

11. Conticelli E. 2019. Compact City as a Model Achieving Sustainable Development. In: Leal Filho W., Azul A., Brandli L., Özuyar P., Wall T. (eds) Sustainable Cities and Communities. Encyclopedia of the UN Sustainable Development Goals. Springer, Cham, 1-10.

12. Eckert R., Huynh L.H.C. 2016. Climate Responsive Neighbourhoods for HCMC: Compact City vs. Urban Landscape. In: Katzschner A., Waibel M., Schwede D., Katzschner L., Schmidt M., Storch H. (eds) Sustainable Ho Chi Minh City: Climate Policies for Emerging Mega Cities. Springer,

13. European Commission. 1994. Charter of European Cities \& Towns Towards Sustainability, European Conference on Sustainable Cities \& Towns in Aalborg, Aalborg.

14. European Commission. 2007. Leipzig Charter on Sustainable European Cities. Leipzig.

15. European Commission - Directorate General for Regional Policy. 2011. Cities of tomorrow - Challenges, visions, ways forward. Luxembourg.

16. Fletcher T. D., Shuster W., Hunt W. F., Ashley R., Butler D., Arthur S., ... Viklander M. 2015. SUDS, LID, BMPs, WSUD and more - The evolution and application of terminology surrounding urban drainage. Urban Water Journal, Vol. 12(7), 525-542. [Access 2.06.2019]. Available at: https://doi.org/10.108 0/1573062x.2014.916314.

17. Getnet K., MacAlister Ch. 2012. Integrated innovations and recommendation domains: Paradigm for developing, scaling-out, and targeting rainwater management innovations, Ecological Economics, Vol. 76, 34-41. [Access 2.08.2019]. Available at: https://doi.org/10.1016/j.ecolecon.2012.02.003.

18. Giridharan R., Emmanuel R., 2018, The impact of urban compactness, comfort strategies and energy consumption on tropical urban heat island intensity: A review., Sustainalble cities and society, Volume 40, July 2018, 677-687.

19. Gordon P. \& Richardson H.W. 1997. Are Compact Cities a Desirable Planning Goal?, Journal of the American Planning Association, 63:1, 95106, DOI: $10.1080 / 01944369708975727$ 
20. Hellstörm D., Jeppsson U., Kärrman E. 2000. A framework for systems analysis of sustainable urban water management. Environmental Impact Assesment Review, Vol. 20, Iss. 3. 311-321.

21. Leopold L.B. 1968. Hydrology for Urban Land Planning - A Guidebook on the Hydrologic Effects of Urban Land Use. In: Geological Survey Circular 554; U.S. Geological Survey: Washington, DC, USA. [Access 2.06.2019]. Available at: https://pubs. usgs.gov/circ/1968/0554/report.pdf.

22. Mairie de Paris, Paris Batignolles Aménagement. 2015. L'éco-quartier. Une référence de développement urbain durable à Paris. Paris.

23. Mairie de Paris. 2016. Zonage d'assainissement de la Ville de Paris. Projet soumis à enquête publique. Annexes au règlement. Paris

24. Mairie de Paris. 2018a. Carte du Zonage Pluvial. Paris.

25. Mairie de Paris. 2018b. Zonage d'assainissement de la ville de Paris - Règlement. Paris.

26. Markowič G., Zeleňáková M., Káposztásová D., Hudáková G. 2014. Rainwater infiltration in the urban areas. WIT Transactions on Ecology and The Environment, Vol. 181, 313-320. DOI: 10.2495/ EID140271

27. MeteoFrance. 2019. Météo et climat, [Access 2.06.2019]. Available at: http://www.meteofrance. com/climat/france/paris/75114001/normales.

28. Oke T. R. 1982. The energetic basis of the urban heat island, Quarterly Journal of the Royal Meteorological Society, 108, 1-24. [Access 2.06.2019]. Available at: http://dx.doi.org/10.1002/qj.49710845502.
29. Oke T. R., Mills G., Christen A., Voogt J.A. 2017. Urban Climates, Cambridge University Press. pp. 519.

30. Skwarzyńska A., Jóźwiakowski K. et. al. 2014. Jakość wód opadowych i ocena możliwości ich wykorzystania w indywidualnych gospodarstwach domowych [The quality of rainwater and evaluation of its use in individual households]. Technologia wody, Vol. 38, 20-23.

31. Słyś D. 2013. Zrównoważone systemy odwodnienia miast [Sustainable urban drainage systems], Dolnośląskie Wydawnictwo Edukacyjne, 280p.

32. Stewart R., Hytiris N. 2008. The Role of Sustainable Urban Drainage Systems in Reducing the Flood Risk Associated with Infrastructure. 11th International Conference on Urban Drainage (11ICUD), $1-15$.

33. Wong, T., R. Brown. 2008. Transitioning to Water Sensitive Cities: Ensuring Resilience through a New Hygrosocial Contract. In: 11th International Conference on Urban Drainage, edited by R. Ashley and A. J. Saul. Edinburgh. September, 10p.

34. Zhang D., Gersberg R.M., Wilhelm Ch., Voigt M. 2009. Decentralized water management: rainwater harvesting and greywater reuse in an urban area of Beijing, China. Urban Water Journal, 6:5, 375385. DOI: $10.1080 / 15730620902934827$.

35. Zhou Q. 2014. A Review of Sustainable Urban Drainage Systems Considering the Climate Change and Urbanization Impacts, Water, Vol. 6, 976-992. DOI:10.3390/w6040976.

36. Zimny H. 2006. Ekologia miasta [Urban Ecology]. Dział Wydawnictw PAN. Kraków, 233 p. 